\title{
The Role of Extensive Reading in Fostering the Development of Grammar and Vocabulary Knowledge
}

\author{
Bünyamin Celik ${ }^{1}$ \\ ${ }^{1}$ Department of Languages, Tishk International University, Erbil, Iraq \\ Correspondence: Bünyamin Celik, Tishk International University, Erbil, Iraq. \\ Email: bunyamin.celik@ishik.edu.iq
}

Received: June 8, $2019 \quad$ Accepted: August 20, $2019 \quad$ Online Published: September 1, 2019

doi: 10.23918/ijsses.v6i1p215

\begin{abstract}
Reading is a complex mental process that consists of different components such as seeing, attending, perceiving, recalling, attaching meaning, synthesizing, analyzing and interpreting. Reading is therefore one of the most important steps in understanding. Training reading is considered important because it includes other basic language skills. Intensive studies are carried out in the field about training reading, how it should be done and the methods to be applied during this education process. Extensive reading has a significant role in extending language proficiency. Extensive reading is effective, in that, it leads to sufficient knowledge of vocabulary and grammar. Learners encounter new words and sentence structures very often during extensive reading; thus, they build familiarity, and multiple exposures to them facilitates learning. Extensive reading will allow learners to engage in the target language constantly that will lead them to master the patterns of the language. This study emphasizes the significance of extensive reading, and focuses on its roles in the development of grammar and vocabulary knowledge.
\end{abstract}

Key Words: Extensive Reading, Comprehension, Vocabulary Knowledge, Grammar Knowledge

\section{Introduction}

Different goals give rise to different needs. This differentiation of needs necessitates the use of different approaches, methods and techniques in foreign language teaching. Reading is defined as understanding a transcribed text by recognizing the letters and analyzing them visually. It is also defined as translating into sounds (Afflerbach, Pearson, \& Paris, 2008). Reading is important both socially and individually. Social reading improves the individual's thinking, behavior, interpersonal relationships and facilitates adaptation to the environment. Individual reading enhances one's view of the world and increases the level of appreciation. The main purpose of reading skills is to enable students to comprehend what they are reading, to attach meaning to words, to enrich their knowledge and vocabulary, to interpret what they read and to benefit from them when necessary (Steel, 2018).

Nation argues that reading and other input sources are practical options in language development for some learners (2001, p.155). Reading materials are useful out of class activities that will help students to develop their language proficiency. Reading is a useful way of promoting language development.

Williams (1984, p. 13) suggests some benefits of reading as:

- Learners can have further practice in the language that they have learnt,

- Learners can practice language in order to reuse it in other skills such as speaking and writing, 
- Learners can learn how to get benefit from the texts to extract the information they need,

- Learners can find enjoyment or interest through reading.

Reading provides a good opportunity for learners to have practice in the target language. Learners will stand a better chance of developing their language skills through reading. Krashen and Terrel (1983) argue that "reading may contribute significantly to competence in a second language. There is good reason, in fact, to hypothesize that reading makes a contribution to overall competence, to all four skills" (Richards \& Rodgers, 2014).

As a matter of fact, the importance given to the use of literary genres in foreign language teaching has increased in recent years. The use of these genres in the classroom environment helps learners to interpret and detect inferences and find hidden and implied meaning. The learner can learn about the life and experiences of the foreign community with the help of the universal topics in these genres. Such texts, providing a multicultural context, make the reading task easier and more appealing, giving learners a fictional, interesting and lifelike experience. In addition, these literary narratives contribute to the development of reading and writing skills by increasing the motivation to learn. When the text is brought into the classroom as a whole without being changed, these written expressions enrich the teaching environment and help the learners understand that they can tell a lot with a few words.

The knowledge and skills that reading activities aim to provide to students vary according to the objectives and characteristics of the program. One of the classifications of reading activities is based on the amount of text read and the effort the student makes. According to this approach, reading activities can be briefly divided into intensive reading, which can be called to examine the text in detail, and extensive reading, which means reading for the purpose of enjoying more. The most important contribution that a teacher can make to a student approaching proficiency level especially during foreign language learning is to develop his self-confidence and to make him feel the value of reading in another language. This can be achieved through extensive reading (Day \& Bamford, 2010). The main purpose of this study is to show that the students who learn foreign languages will use the grammar and grammar rules correctly through extensive reading based reading activities and emphasize that the student's vocabulary can be enriched and it will be easier to learn.

\section{Intensive Reading}

Intensive reading, which is regarded as the first of the foreign language reading activities, aims to teach the reader the relationship between the elements that make up the sentence, and at the same time, to understand the message that will be given by bringing these elements together. In intensive reading programs, students try to understand and translate all the details in the text by carefully reading the short but difficult texts (Nation, 2004). This type of reading program aims to provide students with reading skills such as choosing the main idea, reading between the lines, identifying the equivalents of individual pronouns, and predicting the meaning of new words (Vaughn, Denton, \& Fletcher, 2010). In this type of reading, texts are usually chosen by the teacher according to the objectives of the program and course. The goal of the teacher may be to acquire a reading skill, or to teach a certain grammatical structure and / or to teach some vocabulary. Since the students do not usually have a say in the selection of the text to be studied, the reading piece may not be of interest to the student. Because intensive reading is essential for 
all students to study the same material, texts are usually studied in class and together; the aim is to provide students with the same knowledge and skills (Nation, 2008). In order to achieve higher efficiency, the text should be short and targeted. The determined text is divided into sentences to be examined in detail in terms of structure and shape. The target words and sayings are emphasized, and studies are deemed necessary for the consolidation of words and structures (Tanaka \& Stapleton, 2007). The meaning of these words can be given directly by the teacher, or may be found in the dictionary and / or extracted from the context. Breaks to find out the meaning of a large number of unknown words (to look at the dictionary or ask the teacher, etc.) may hinder the speed and fluency of reading (Mart, 2015). In addition, since a text containing many new structures and words will discourage the student, the texts to be studied are sorted from easy to difficult considering the cognitive levels of the students. However, while one text is seen as easy by some students, it may be difficult for others (Berardo, 2006).

Intensive reading often requires intensive attention, as it requires a large number of words and structures to be learned in a short period of time. These detailed and intensive studies can give students the ability to concentrate on any text. In other words, in this way the student has the chance to develop both general skills and vocabulary and structure knowledge. During intensive reading, the attention of the student can be raised to the highest level with the effort of the teacher and distracted less. In addition, students acquire some general reading skills that they can use in their own language and foreign language. Reading skill includes many skills such as separating the main idea from the details, extracting the meaning of the unknown word from the context, comparing their idea with the idea in the text being read and reading between the lines. These skills can also be gained by carefully planning intensive reading activities.

\section{Extensive Reading}

Extensive reading is described as an effort to read abundantly to understand texts in general terms (without going into detail) (Brown, 2002). In this type of reading, Brown states that the reader is not interested in the meaning of the words and/or sentences individually, but is interested in the general meaning of the text, and that the main purpose is to enable the student to read more literary texts. In such a program, students read a lot, most of them outside the school. This type of reading is a superficial type of reading (Yamashita, 2008) and does not require high concentration, so it can be done in any environment, for example when traveling, waiting for public transport or anyone. According to Renandya (2007), this reading should be planned and conducted in such a way that the teacher's pressure is not felt and encouraged to read by himself. Al-Homoud \& Schmitt (2009) states that such studies can be carried out in the classroom but should be carried out in a manner appropriate to the characteristics of the program. According to Al-Homoud \& Schmitt, when students acquire the appropriate skills, these studies should be left to students outside the classroom. Walter (2003) emphasizes the need for the student to reach a certain level in order to benefit more from such reading.

As the reasons and subjects of daily readings vary, they are usually done with pleasure. For this reason, reading texts from different fields and different levels are selected for extensive reading. In addition, a large number of reading materials should be available at the institution where such a program will be conducted. Moreover, the student should select the texts to be read in the extensive reading applications (Day \& Bamford, 2010). Students' interest is in the forefront, and even if any text does not interest the student, the student has the freedom to stop reading the material. In other words, it is the student who 
decides what to read and how much to read and he/ he should not be forced to do what others ask for. The student tends to read what he thinks he will enjoy, learn and/or understand. If he does not enjoy reading, does not learn anything and/or does not understand the text, reading this material will mean nothing to the student. Therefore, students' level of interest, knowledge and understanding of language are the most important criteria that determine the appropriateness of the text to be read (Flanagan \& Custance, 2018; Renandya, 2007). Comprehensive reading activities are mostly individual and quiet, the student chooses the place and time and reads at his own pace and mostly outside the school (Day \& Bamford, 2010; Renandya, 2007). Since easier-to-understand texts will be used, reading will be faster and more texts can be read in a given period of time. In this way, the student is confronted with a more comprehensible input. In this approach, it is recommended that the teacher has an impact that directs the students to the goals but the teacher's impact should not be very obvious. The teacher should explain the approach to the students, keep a record of what the students read, and guide them to the highest benefit. According to Al-Homoud \& Schmitt (2009), in this approach, with their attitude towards reading, the teacher is expected to be a good model.

It has been widely advocated that extensive reading makes a major contribution to language proficiency particularly through developing grammar and vocabulary knowledge. Extensive reading has been proven to provide gains in building a better vocabulary and enhancing grammatical awareness. Extensive reading is carried out to get an overall understanding of the materials (Day \&Bamford,1998). Extensive reading is a process of acquiring meaning. In order to have a good command of L2, learners read abundantly by focusing on the meaning of the text. Hafiz and Tudor states the aim of extensive reading as "to 'flood" learners with large quantities of L2 input with few or possibly no specific tasks to perform on this material" (1989, p. 5). When learners are provided abundant L2 materials, they are able to learn the target language with ease. Meaningful materials in foreign language learning will absorb the attention of learners and facilitate learning process. Extensive reading is a learning tool intended to extend learners' knowledge of the language. It will help learners with reinforcement of vocabulary and grammar knowledge.

\subsection{The Benefits of Extensive Reading}

In order to be a good reader, the student must read enough material. If the selected texts are appropriate to the level of the student, the readings will provide the comprehensible input required for language acquisition (Nation, 2004). It is known that most of the students do not have the opportunity to practice the foreign language and the schools do not have the means to overcome this deficiency. If planned, Extensive Reading studies will allow the student to see what he / she has learned in the text, analyze it and develop their language accordingly (Krashen, 1982). Here, planning means that the material is attractive to the student's level and given to students' grade by grade, and that the structure and words used do not create problems for the student (Vaughn, Denton, \& Fletcher, 2010).

Extensive reading is briefly defined as "experiences of reading extended texts for extended periods of time" (Grabe \& Stoller, 2011). Extensive reading has a facilitating role of language development.

Dubin and Olshtain, (1977) state the benefits of extensive reading as:

- Students develop an ability to gain pleasure and also satisfaction from

- Reading on their own in the language they are learning. 
- They are exposed to the language in a more natural and less structured way. In other words, they get different unpressured feeling on the structure of the language since they read for pleasure, and not for a grade or a test.

- Extensive reading has also effect on other language skills such as writing and speaking.

- Extensive reading, or reading for pleasure, will help the students comprehend more and also continue to use the language after the instruction.

Extensive reading will highly contribute to reading comprehension (Davis, 1995; Krashen, 1993; Nation, 1997); positive attitudes towards learning (Dupuy et al., 1996); enriching vocabulary (Tannenbaum et al., 2006; Cho \& Krashen, 1994; Nation, 1997); grammar knowledge and seeing the relationship among words (Mccarthy, 2000; Elley, 1991); advancing listening and speaking skills (Mich, Pianta \& Mana, 2013); and enhancing writing skills (Tsang, 1996).

\section{Developing Vocabulary Knowledge through Extensive Reading}

A lot of studies focus on the connection between reading and expanding vocabulary knowledge. As Eskey puts it "the relationship between reading and vocabulary is well documented and reciprocal" (2005, p. 567). Extensive reading is highly productive vocabulary builder (LeLoup \& Ponterio, 2005). Therefore, those who read enormously will stand a better chance of building up vocabulary knowledge (Mart, 2012a; Mart 2012b). Reading leads to gains in vocabulary. Nations argues that "Reading has long been seen as a major source of vocabulary growth" (Nation, 1995).

Alderson (2000) states that reading is built from two components: word recognition and comprehension. Comprehension holds an important place in reading; therefore, learners advance their knowledge if comprehension occurs. Through extensive reading learners repeatedly encounter new words. Exposure to new words very often will create familiarity. Peregoy and Boylecomment state that "familiarity with text types facilitates reading comprehension" (2000, p.240). Multiple encounters with the new words will result in better learning. As learners meet new words in materials, they will recognize them, and comprehension which will lead to vocabulary learning will occur.

Similarly, Day and Bamford (1998) suggest that extensive reading highly contributes to learning language elements. Learners will have the opportunity to learn new words through extensive reading as they encounter new vocabulary in the materials. Flanagan \& Custance (2018) suggest that learners can enhance their vocabulary growth with ease through reading. Extensive reading is useful in that it will allow learners to learn previously unknown words. Grabe (1991) notes some benefits of extensive reading as "Longer concentrated periods of silent reading build vocabulary and structural awareness, develop automaticity, enhance background knowledge, improve comprehension skills, and promote confidence and motivation" (p. 396).

Extensive reading increases motivation of learners, and it provides an enjoyable learning environment. Constant new word encounters improve word-recognition fluency; therefore, develop automaticity. Automatic recognition of words will improve vocabulary knowledge. Extensive reading has been an important source of enriching vocabulary knowledge. When learners increase their known words, they will achieve better comprehension. As learners achieve more comprehension, their knowledge of language will increase; consequently, as Hedge (1985) comments their eagerness to learn will develop naturally. 
Extensive reading another benefit to vocabulary learning is related to repetitions that appear to be unnecessary in the text. In a short text of intense reading, the student encounters many new words and structures. This kind of reading overloads the brain. All of this new information cannot be processed and transferred to long-term memory, and a significant part of the information is lost without being noticed by the student. In addition, everyday language is not so heavy. In spoken language and in daily readings, there is a lot of unnecessary information. This reduces the amount of information that needs to be transferred to long-term memory; it makes reading and/or listening easier and understandable. This relaxes the student and increases the speed, comprehension and the amount of text that can be read (Yamashita, 2008). However, because it requires a weaker focus, the student's interest may dissipate more quickly and move away from the activity. In this context, during reading, the student's existing cognitive structures (schemata) come into play and facilitate the understanding of the text (Walter, 2006). Another contribution of these schemes to reading skills is that they provide a platform for predicting new words encountered in the text and sometimes facilitate the understanding of structures. As students read, these structures take action and help the reader analyze and interpret the message.

\section{Developing Grammar Knowledge through Extensive Reading}

Teaching grammar is a controversial topic in research and teaching in the second language (L2). Although the rise of communicative language teaching draws attention to grammar by both researchers and L2 instructors, recent studies have revised the important role of grammar in L2 learning and have shown that grammar teaching helps students achieve a higher level of language skills (eg, Ellis, 2002; Norris \& Ortega, 2000).

Research in the literature over the last 15 years shows that grammar and reading ability are strongly related to general grammar and that reading is an important determinant of understanding (Jung, 2009; Zhang, 2012). Extensive reading provides learners exposure to how language works. It will allow seeing relationships among words, and concepts (Hancock, 1998). Learners master the language with ease if they see how words fit together in a sentence. Hedgcock \& Ferris (2009) comment that "Extensive reading naturally exposes readers to naturally-occurring phrasal and clausal patterns, repeated and alternate uses of lexical items and their spellings, and a range of other graph logical features such as paragraphing, punctuation, and capitalization conventions" (p.213). Learners will see the sentence structures through extensive reading; as a result, they will develop their grammar knowledge.

\section{Conclusion}

Reading enables the individual to learn and learn, but also develops the individual in many different ways. It directs their behavior and relationships with others, enriches their inner world, expands their perspective, enables them to look at their environment without prejudice, increases the level of appreciation, enables them to gain the habit of thinking and creating and evaluating, and enhances the individual's ability to use language (Mich, Pianta, \& Mana, 2013).

Since reading skill is very important especially in academic terms compared to other language skills, it is the skill that students who learn English as a foreign language give the most importance in the target language. In this context, it is appropriate for the students to be aware of the factors affecting the reading process and to keep the reading processes under control in this direction. For example, it is very important 
to improve students' vocabulary and grammar knowledge, especially in order to improve their reading skills and to make more use of comprehensive reading activities, in order to ensure that they can be sufficient in general in the target language. With Extensive Reading, students will have the opportunity to develop new reading strategies both in the classroom and under the control of teachers in a classroom, as well as to apply new strategies on their own (Nation, 2015). Reading is one of the important methods of continuous learning and thus meeting the requirements arising in time. In this respect, learners will build better vocabulary and grammar knowledge if they constantly engage in the target language. Extensive reading will highly contribute to enrichment of vocabulary and grammar knowledge. Extensive Reading will allow learners to develop automaticity since they will frequently encounter new words, at the same time they will enhance their grammatical awareness as they will see the relationship among words in sentences.

\section{References}

Afflerbach, P., Pearson, P. D., \& Paris, S. G. (2008). Clarifying differences between reading skills and reading strategies. The Reading Teacher, 61(5), 364-373. https://doi.org/10.1598/RT.61.5.1

Alderson, J. C. (2000). Assessing reading. Cambridge: Cambridge University.

Al-Homoud, F., \& Schmitt, N. (2009). Extensive reading in a challenging environment: A comparison of extensive and intensive reading approaches in Saudi Arabia. Language Teaching Research, 13(4), 383-401.

Berardo, S. A. (2006). The use of authentic materials in the teaching of reading. The Reading Matrix, 6(2), 60-69.

Brown, H. D. (2002). English language teaching in the "post-method" era: Toward better diagnosis, treatment, and assessment. Methodology in language teaching: An anthology of current practice, 9-18.

Celik, B. (2018). Effects of Extensive Reading on Learners: How It Develops Certain Points in Vocabulary and Sentence Structure. International Journal of English Linguistics, 8 (2), 73-84. https://doi: 10.5539/ijel.v8n2p73

Cunningham, A. E., \& Stanovich, K. E. (1998). What reading does for the mind. American Educator, 22(1), 8-15.

Davis, C. (1995). Extensive reading: An expensive extravagance? ELT Journal, 49, 329-335.

Day, R. R., \& Bamford, J. (2010). The benefits of extensive reading (ER).

Day, R.R., \& Bamford, J. (1988). Teaching reading. Annual Review of Applied Linguistics, 18, 124-41.

Dubin, F., \& Olshtain, E. (1977). Facilitating language learning: A guidebook for the ESL/EFL teacher. N.Y: McGrow: Hill International Book Company.

Dupuy, B., Tse, L., \& Cook, T. (1996). Bring books into the classroom: first steps in turning collegelevel ESL students into readers. TESOL Journal, 5, 10-15.

Elley, W. B. (1991). Acquiring literacy in a second language: The effect of book-based programs. Language Learning, 41, 375-411.

Ellis, R. (2002). Does form-focused instruction affect the acquisition of implicit knowledge? Studies in Second Language Acquisition, 24, 223-236.

Eskey, D. (2005). Reading in a Second Language. In E. Hinkel (Ed), Handbook of research on second language teaching and learning (pp. 563-580). Mahvah, NJ: Lawrence Erlbaum.

Flanagan, A., \& Custance, I. (2018). Reading attitudes and extensive reading at the secondary level. OSAKA JALT, 106.

Grabe, W. (1991). Current developments in second language research. TESOL Quarterly, 25, 375-406

Grabe, W., \& Stoller, F. L. (2011). Teaching and researching reading (2nd ed.). Harlow: Pearson. 
Hafiz, F.M., \& Todor, I. (1989). Extensive reading and the development of language skills. ELT Journal, 34(1), 5-13. http://dx.doi.org/10.1093/elt/43.1.4

Hancock, O.H. (1998). Reading skills for college students (4th ed.). Upper Saddle Rivers, NJ: Prentice Hall.

Hedgcock, J.S., \& Ferris, D.R. (2009). Teaching readers of English. New York: Routledge.

Hedge, T. (1985). Using readers in language teaching. Hertfordshire: Modern English Publications.

Krashen, S. D. (1993). The power of reading: Insight from the research. Englewood, CO: Libraries Unlimited.

Krashen, S. D., \& Terrell, T. D. (1983). The Natural Approach: Language acquisition in the classroom. Oxford and San Francisco: Pergamon, Almany.

Jung, J. (2009). Second language reading and the role of grammar. Studies in Applied Linguistics and TESOL, 9(2), 29-48.

LeLoup, J., \& Ponterio, R. (2005). Vocabulary support for independent online reading. Language, Learning \& Technology, 9 (2). Retrieved on October 20, 2005 from www.questia.com

Mart, C. T. (2015). Combining extensive and intensive reading to reinforce language learning. Journal of Educational and Instructional Studies in the World, 5(4), 85-90.

Mart, C.T. (2012a). Developing speaking skills through reading. International Journal of English Linguistics, 2 (6), 91-96.

Mart, C.T. (2012b). Encouraging young learners to learn English through stories. English Language Teaching, 5 (5), 101-106.

Mccarthy, F. (2000). Lexical and grammatical knowledge in reading and listening comprehension by foreign language learners of Spanish. Applied Language Learning, 11, 323-348.

Mich, O., Pianta, E., \& Mana, N. (2013). Interactive stories and exercises with dynamic feedback for improving reading comprehension skills in deaf children. Computers \& Education, 65, 34-44. https://doi.org/10.1016/j.compedu.2013.01.016

Nation, I. S. P. (2008). Teaching ESL/EFL reading and writing. Routledge.

Nation, I. S. P. (1995-6). Best practice in vocabulary teaching and learning. EA Journal, 3(2), 7-15.

Nation, I. S. P. (2001). Learning vocabulary in another language. Cambridge: Cambridge University Press.

Nation, P. (1997). The language learning benefits of extensive reading. The Language Teacher, 21, 1316.

Nation, P. (2004). Vocabulary learning and intensive reading. English Australia Journal, 21(2), 20.

Nation, P. (2015). Principles guiding vocabulary learning through extensive reading. Reading in a Foreign Language, 27(1), 136-145.

Norris, J., \& Ortega, L. (2000). Effectiveness of L2 instruction: a research synthesis and quantitative meta-analysis. Language Learning, 50, 417-528

Peregoy S., \& Boyle, O. F. (2000). English Learners Reading English: What we know, what we need to know. Theory into Practice, 39 (4), 237-247.

Renandya, W. A. (2007). The power of extensive reading. RELC Journal, 38(2), 133-149.

Richards, J. C., \& Rodgers, T. S. (2014). Approaches and methods in language teaching. Cambridge university press.

Tanaka, H., \& Stapleton, P. (2007). Increasing reading input in Japanese high school EFL classrooms: An empirical study exploring the efficacy of extensive reading. The Reading Matrix, 7(1), $115-131$.

Tannenbaum, R. K., Joseph, K. T., \& Richard K. W. (2006). Relationships between word knowledge and reading comprehension in third-grade children. Scientific Studies of Reading, 10(4), 381-398.

Tsang, W.K. (1996). Comparing the effects of reading and writing on writing performance. Applied Linguistics, 17, 210-233. 
Vaughn, S., Denton, C. A., \& Fletcher, J. M. (2010). Why intensive interventions are necessary for students with severe reading difficulties. Psychology in the Schools, 47(5), 432-444. https://doi.org/10.1002/pits.20481

Walter, H. C. (2003). Reading in a second language. Subject Centre for Languages, Linguistics and Area Studies Good Practice Guide.

Williams, E. (1984). Reading in the language classroom. London: Macmillan Publishers Ltd.

Yamashita, J. (2008). Extensive reading and development of different aspects of L2 proficiency. System, 36(4), 661-672.

Zhang, D. (2012). Vocabulary and grammar knowledge in second language reading comprehension: A structural equation modeling study. The Modern Language Journal, 96(4), 558-575. https://doi.org/10.1111/j.1540-4781.2012.01398.x 